\title{
Skin-on-a-Chip Technology for Testing Transdermal Drug Delivery-Starting Points and Recent Developments
}

\author{
Zsófia Varga-Medveczky, Dorottya Kocsis $\mathbb{1}$, Márton Bese Naszlady, Katalin Fónagy and Franciska Erdő * \\ Faculty of Information Technology and Bionics, Pázmány Péter Catholic University, Práter u. 50a, \\ H-1083 Budapest, Hungary; varga-medveczky.zsofia@itk.ppke.hu (Z.V.-M.); kocsis.dorottya@itk.ppke.hu (D.K.); \\ naszlady.marton.bese@itk.ppke.hu (M.B.N.); fonagy.katalin@ppke.hu (K.F.) \\ * Correspondence: erdo.franciska@itk.ppke.hu
}

Citation: Varga-Medveczky, Z.; Kocsis, D.; Naszlady, M.B.; Fónagy, K.; Erdő, F. Skin-on-a-Chip Technology for Testing Transdermal Drug Delivery-Starting Points and Recent Developments. Pharmaceutics 2021, 13 , 1852. https://doi.org/10.3390/ pharmaceutics13111852

Academic Editors: Romána Zelkó and Istvan Antal

Received: 7 September 2021

Accepted: 27 October 2021

Published: 3 November 2021

Publisher's Note: MDPI stays neutral with regard to jurisdictional claims in published maps and institutional affiliations.

Copyright: (c) 2021 by the authors. Licensee MDPI, Basel, Switzerland. This article is an open access article distributed under the terms and conditions of the Creative Commons Attribution (CC BY) license (https:// creativecommons.org/licenses/by/ $4.0 /)$.
Abstract: During the last decades, several technologies were developed for testing drug delivery through the dermal barrier. Investigation of drug penetration across the skin can be important in topical pharmaceutical formulations and also in cosmeto-science. The state-of- the-art in the field of skin diffusion measurements, different devices, and diffusion platforms used, are summarized in the introductory part of this review. Then the methodologies applied at Pázmány Péter Catholic University are shown in detail. The main testing platforms (Franz diffusion cells, skin-on-a-chip devices) and the major scientific projects (P-glycoprotein interaction in the skin; new skin equivalents for diffusion purposes) are also presented in one section. The main achievements of our research are briefly summarized: (1) new skin-on-a-chip microfluidic devices were validated as tools for drug penetration studies for the skin; (2) P-glycoprotein transport has an absorptive orientation in the skin; (3) skin samples cannot be used for transporter interaction studies after freezing and thawing; (4) penetration of hydrophilic model drugs is lower in aged than in young skin; (5) mechanical sensitization is needed for excised rodent and pig skins for drug absorption measurements. Our validated skin-on-a-chip platform is available for other research groups to use for testing and for utilizing it for different purposes.

Keywords: topical drug diffusion; skin-on-a-chip; microfluidics; Franz diffusion cells; skin equivalents; drug delivery

\section{State of-the-Art in Testing Topical Drug Absorption and Delivery}

Transdermal drug delivery has a high importance as an alternative to traditional routes of drug administration (e.g., per os and intravenous). It means that noninvasive drug administration and transdermal drugs are able to bypass the liver first pass metabolism and reduce the likelihood of side effects due to lower systemic exposure.

Topical drug administration and drug formulation has had a renaissance during the last decades. The target organ of the topically applied drugs can be the skin itself, but several other therapeutic indications are also possible (pain, inflammation, central nervous system effects, humoral effects, etc.), which can be treated by transdermal drug delivery. Testing the drug penetration through the dermal barrier is an important task in the development of new drug formulations in pharmacokinetic/pharmacodynamic (PK/PD) profiling studies and in dermatology. In addition to cosmeto-scientific research, there is a need to test the transcutaneous absorption of active and cosmetic ingredients. To fully utilize the potential of the topical administration route, it is important to optimize the delivery of active ingredients/drugs into or through the skin. The optimization of carrier/vehicle composition is very important at the early phases of product development. A rational approach in designing and optimizing skin formulations requires well-defined skin models, which are able to identify and evaluate the intrinsic properties of the formulation. Most of the current optimization methods rely on the use of suitable ex vivo animal/human 
models. However, increasing restrictions in the use and handling of animals and human skin stimulated the research for suitable artificial skin models as well.

Currently, as a first approach, in silico studies have been performed as a substitute of in vivo testing to simulate the drug absorption through the skin in the early phase. In silico physiological modeling is critical for predicting dermal exposure to therapeutics and assessing the impact of different formulations on transdermal distribution [1]. VeriSIM Life (VSL) has developed BIOiSIM, a dynamic, biology-driven model which provides a scalable computational solution through the use of machine learning (ML) integrated physiological modeling to make fast predictions that can be applied to larger compound datasets. Integration of ML with mechanistic modeling allows BIOiSIM to complete biological datasets [1].

The next step in the complexity order of testing platforms is the use of in vitro skin models. There exist different model membranes for testing drug permeability: (1) nonlipid based membranes such as silicone membranes and the Strat- $\mathrm{M}^{\mathrm{TM}}$ membrane, which is composed of multiple layers of polyether sulfone, creating a morphology similar to human skin, including a very tight surface layer (stratum corneum) and (2) lipid-based model membranes, e.g., parallel artificial membrane permeability assay/PAMPA/and phospholipid vesicle-based permeation assay/PVPA/etc.) [2]. The structure of the PAMPA and PVPA systems are shown in Figures 1 and 2.

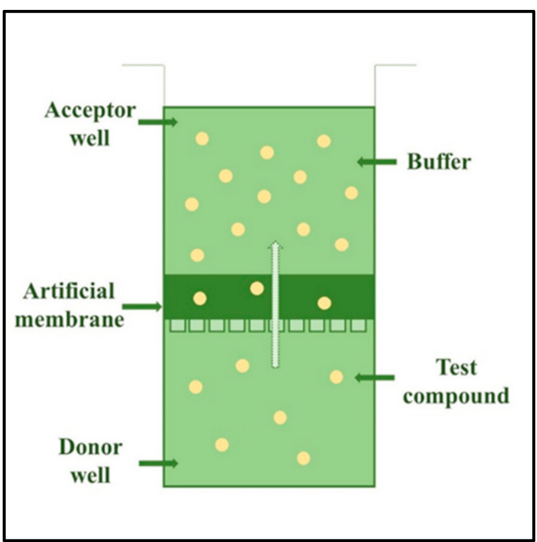

Figure 1. The structure of one-well of a 96-well plate of a parallel artificial membrane permeability assay (PAMPA) system.
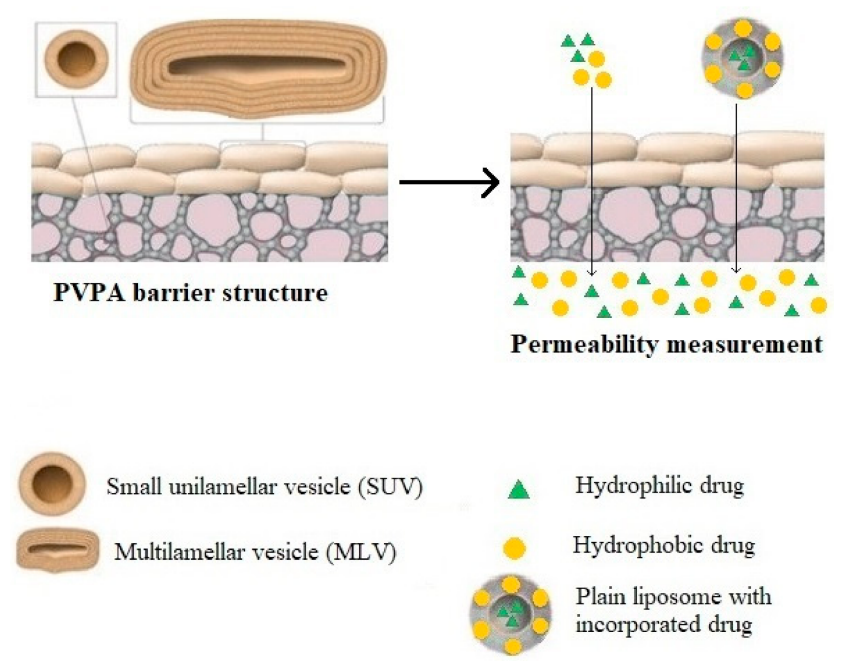

Figure 2. The phospholipid vesicle-based permeation assay (PVPA), mimicking the stratum corneum. It consists of a tight barrier of liposomes deposited on a cellular ester filter support. 
In vitro skin cell culturing has greatly developed over the last decades and it is now a well-established technology in drug testing. Although many models have been designed to assess tissue responses to the application of irritants or upon wound healing, the absence of immune cells limits their physiological relevance, underlining the need for more advanced models that better mimic human physiological responses that would lead to the replacement of animal models. In vivo, the skin response to inflammation not only involves tissue-resident cells, but also a range of immune cells that are recruited after pro-inflammatory signals, which are released at the site of injury in the skin [3]. Depending on the application, different cell types have been included in skin cultures (keratinocytes, fibroblasts, melanocytes, macrophages, etc.), however, the inclusion strategies, scaffolds, cell sources, culture media, and culture times are highly heterogeneous [4-6]. Keratinocyte cultures serve as a skin model cultivated with collagen in different types of scaffolds. $\mathrm{HaCaT}$ cells are immortalized human keratinocytes and have been extensively used to study the epidermal homeostasis and pathophysiology [7].

To make more reproducible models, reconstructed human epidermis or full thickness skin models have been developed. As cell-based techniques, these skin models are useful tools for testing the phototoxicity, corrosivity, and irritancy, as well as drug permeability. Recently, the models were also utilized in the optimization of vehicle composition of different topical formulations.

\section{Diffusion Studies}

For the assessment of topical drug absorption through the skin, different technical solutions (devices and equipment) are available. Additionally, for drug penetration testing, various transport surface materials and biological systems have been developed. The different methodological arrangements have advantages and weaknesses. The right selection of the sufficient model is determined by the question to be answered. This can be related to the number of compounds/formulations to be investigated, the amount of the test substances and vehicle available, the dimensions of the diffusion surface materials (membrane, cell culture monolayer, excised skin) and the time factor. In addition, the costs can be considered as a determining factor in the decision. In the following Sections 2.1 and 2.2, the most widely used technologies, diffusion platforms, and objects are discussed.

\subsection{The Testing Platforms-Technologies}

\subsubsection{Diffusion Cells}

One of the most common methodologies for studying transdermal drug delivery in vitro or ex vivo are the diffusion cell systems. The first equipment was developed and described by Thomas J. Franz [8]—however, nowadays several subgroups can be distinguished based on the different parameters such as the orientation (horizontal vs. vertical), geometry, and volume of the compartments, or dynamics of the fluid flow in the receptor chamber (static vs. flow-through).

In general, the diffusion cells consist of a donor and a receptor compartment, separated by a barrier, i.e., an artificial membrane, cell culture, or skin sample. In the static diffusion cells, the receptor chamber solution is continuously stirred with a magnetic bar to provide the uniform distribution of the penetrated substance. The solution is sampled and replaced with a new receptor fluid at each time point, which can be performed either manually or automatically. The $\mu$ FLUX ${ }^{\mathrm{TM}}$ diffusion cell (Pion Inc., Billerica, MA, USA) is a horizontal diffusion cell system where the compartments are divided by a synthetic membrane. It is mostly applied for studying the permeation and dissolution of poorly water soluble drug candidates [9]. A further horizontal set-up is the Side-Bi-Side ${ }^{\mathrm{TM}}$ (PermeGear, Hellertown, PA, USA) diffusion cell system, which is suitable for studying the blood-brain barrier or the nasal pathway [10]. A special chamber has been developed for imitating the surface of the cornea, as well. Moreover, the real-time impedance measurement is also possible in both chambers. The Navicyte Horizontal Diffusion Chamber System (Warner Instruments, Holliston, MA, USA) is usually used for studying toxicology or transport mechanisms 
in interfaces which are exposed to air (for instance dermal, pulmonary, corneal, or nasal cells) [11]. The vertical arrangement of the Navicyte system has also been developed, which is primarily designed for work with excised tissue segments and mostly used for the characterization of the intestinal, corneal, or nasal permeability [12-14]. The vertically oriented Franz diffusion cell system (Teledyne Hanson Research, Chatsworth, CA, USA) is one of the "gold-standard" methods for the investigation of the transdermal drug delivery, which is suitable for studying artificial membranes and ex vivo skin samples [15,16]. Beside the transdermal route, several examples are known for Franz cell experiments, studying the nasal, corneal as well as the transbuccal administration [10,17-19].

The other group of diffusion cells are the "flow-through" cells, which require a pump to ensure the continuous fluid flow through the receptor chamber. It maintains the sink conditions during the experiment, which is beneficial in the case of drugs having large permeability coefficients [20], moreover this feature simulates the in vivo conditions better than the static mode. The In-Line Cells from PermeGear (Hellertown, PA, USA) are flow-through vertical diffusion cell systems available on the market. Various types of experiments using in-line cells can be found in the literature, such as examination of synthetic membranes mimicking human skin, ex vivo animal, and human skin or even nail samples or buccal membranes [21-23]. A vertical, flow-through diffusion cell system has also been developed by our research group, which is described in details in Section 4 . The different diffusion cell types are summarized in Table 1.

Table 1. Comparison of different diffusion cell types.

\begin{tabular}{|c|c|c|c|c|}
\hline $\begin{array}{l}\text { Trade Name of } \\
\text { the Device }\end{array}$ & Manufacturer & Structure & Applications & References \\
\hline$\mu F_{L U X}{ }^{\mathrm{TM}}$ & $\begin{array}{l}\text { Pion Inc., } \\
\text { Billerica, MA, } \\
\text { USA }\end{array}$ & $\begin{array}{c}\text { Static, } \\
\text { horizontal }\end{array}$ & $\begin{array}{c}\text { Determination of the } \\
\text { intrinsic permeability } \\
\text { coefficients, } \\
\text { dissolution-permeation } \\
\text { study of poorly } \\
\text { water-soluble candidates } \\
\text { through artificial } \\
\text { membranes }\end{array}$ & {$[9,24]$} \\
\hline Side-Bi-Side ${ }^{\mathrm{TM}}$ & $\begin{array}{l}\text { PermeGear, } \\
\text { Hellertown, } \\
\text { PA, USA }\end{array}$ & $\begin{array}{c}\text { Static, } \\
\text { horizontal }\end{array}$ & $\begin{array}{l}\text { Studying the transport } \\
\text { mechanism in the } \\
\text { blood-brain-barrier and in } \\
\text { the cornea, investigation of } \\
\text { the nasal dosage forms }\end{array}$ & {$[10,25]$} \\
\hline $\begin{array}{c}\text { Navicyte } \\
\text { Horizontal } \\
\text { Diffusion } \\
\text { Chamber System }\end{array}$ & $\begin{array}{c}\text { Warner } \\
\text { Instruments, } \\
\text { Holliston, MA, } \\
\text { USA }\end{array}$ & $\begin{array}{c}\text { Static, } \\
\text { horizontal }\end{array}$ & $\begin{array}{c}\text { Investigation of the } \\
\text { toxicology or transport } \\
\text { mechanisms in interfaces } \\
\text { exposed to air (dermal, } \\
\text { pulmonary, corneal, nasal } \\
\text { cells) }\end{array}$ & {$[10,26]$} \\
\hline $\begin{array}{c}\text { Navicyte } \\
\text { Vertical } \\
\text { Diffusion } \\
\text { Chamber System }\end{array}$ & $\begin{array}{c}\text { Warner } \\
\text { Instruments, } \\
\text { Holliston, MA, } \\
\text { USA }\end{array}$ & $\begin{array}{c}\text { Static, } \\
\text { vertical }\end{array}$ & $\begin{array}{c}\text { Characterization of the } \\
\text { intestinal, corneal, or nasal } \\
\text { permeability }\end{array}$ & [12-14] \\
\hline $\begin{array}{c}\text { Franz-Diffusion } \\
\text { Cell }\end{array}$ & $\begin{array}{l}\text { Teledyne } \\
\text { Hanson } \\
\text { Research, } \\
\text { Chatsworth, } \\
\text { CA, USA }\end{array}$ & $\begin{array}{c}\text { Static, } \\
\text { vertical }\end{array}$ & $\begin{array}{l}\text { Investigation of the } \\
\text { transdermal, nasal, corneal, } \\
\text { or transbuccal } \\
\text { administration }\end{array}$ & [10,17-19] \\
\hline In-Line Cells & $\begin{array}{l}\text { PermeGear, } \\
\text { Hellertown, } \\
\text { PA, USA }\end{array}$ & $\begin{array}{l}\text { Flow- } \\
\text { through, } \\
\text { vertical }\end{array}$ & $\begin{array}{l}\text { Studies for artificial or ex } \\
\text { vivo skin or nail samples, or } \\
\text { buccal membranes }\end{array}$ & {$[21-23]$} \\
\hline
\end{tabular}




\subsubsection{Organ-on-a-Chip Systems}

Predicting the pharmacokinetic and dynamic properties of the candidate drugs is resource- and time-consuming, moreover the translational possibilities of the 2D cell culture and animal models are limited.

A novel, alternative approach is provided by the so-called organ-on-a-chip systems. It utilizes the advanced techniques of microfabrication and tissue engineering, which also enables to eliminate the discrepancy between the human and animal organs, as well as the problems of the low availability of human samples. These systems overcome the problem of the homogenous cell cultures, since the complex interactions of cell and tissue types can be reproduced.

Moreover, tissue barriers, parenchymal tissues, and interorgan interactions can be mimicked as well [27]. There are organ-on-a-chip methods for imitating the lung, heart, liver, kidney, intestine, muscle and placenta [27,28]. Models showing both physiological and non-physiological conditions can be designed, which are proper disease models, such as various tumors [27] or skin diseases described in Section 5 as well.

The ultimate goal is to fabricate a "body-on-a-chip" device, which includes multiple microscale cellular environments simulating the systematic function of a human organism. Such a kind of chip could be used to study a complex pharmacokinetic profile of drugs, covering the absorption, distribution, metabolism and excretion. However, the proper, physiologically relevant scaling of the different organs remain a challenge, moreover the cost of manufacturing is relatively high $[27,28]$.

Currently there is only a few examples for the application of different drug formulations in skin-on-a-chip systems $[29,30]$. The most used forms are creams and gels, but other solid, semisolid or liquid formulations can also be used in such devices. For a summary of conventional and novel topical drug dosage forms that can be tested in skin-on-a-chip device, see Tables 2 and 3. [31].

Table 2. Different topical dosage forms that can be used in miniaturized diffusion cell device.

\begin{tabular}{cr}
\hline & Conventional Topical Dosage Forms \\
\hline Solids & Powders, plasters \\
\hline Liquids & Lotions, solutions, suspensions, collodions, liniments, emulsions \\
\hline Semi-solids & Ointments, creams, pastes, gels, suppositories \\
\hline Miscellaneous & Transdermal delivery systems, alcohols, medical tapes \\
\hline
\end{tabular}

Table 3. Novel topical dosage forms that can be used in miniaturized diffusion cell device.

\begin{tabular}{l}
\hline Novel Topical Dosage Forms \\
\hline Novel gels \\
Aerosol foams \\
Microsponges \\
Muco- and bio-adhesives \\
Novel vesicular carriers \\
Nano-emulsions and nano-emulgels \\
Proteins and peptides \\
Polymers \\
Emulsifier-free formulations \\
Fullerenes
\end{tabular}

\subsection{The Diffusion Objects (Diffusion Surfaces)}

\subsubsection{In Vitro Cell Culture Models}

A huge milestone was achieved in the field of skin models by Rheinwald and Green in 1975. They used lethally irradiated 3T3 fibroblasts as feeder layers to create cultures of human keratinocyte colonies from keratinocyte from human skin biopsy. 
This discovery made it possible for the scientists to generate large quantities of keratinocytes for in vitro cell culture studies and gave a perspective for the treatment of burning injury patients [32-35]. Rheinwald and Green were also the first to describe that such monolayer cultures can differentiate and form multilayered structures [36]. Their method was further developed by many research groups, for a recent application see Wufuer et al., 2016 [37]. Simplicity and reproducibility are major advantages of monolayer keratinocyte cultures. However, many features of epidermis are lacking in this model and keratinocytes are forced to adapt to artificial circumstances [38].

\subsubsection{Human Reconstructed Tissues Models}

In the past 10 years, several tissue culture-based 3D human skin models have been developed and become commercially available [39]. They are usually classified as human reconstructed epidermis models (e.g., EpiSkin, SkinEthic, EpiDerm) and living full thickness skin equivalent models (GraftSkin, EpiDermFT, Pheninon). The models are composed of the human cells grown as the tissue culture and matrix equivalents normally present in the skin [40,41]. These models have numerous application possibilities: skin irritation, corrosion, hydration, drug delivery, anti-aging, UV protection, anti-psoriatic, and anti-melanoma drug diffusion testing, etc. For a summary of the applications of the marketed products, see Table 4 [42-48].

\subsubsection{Ex Vivo Excised Skin Models}

Numerous articles reported on the evaluation of skin formulations based on the use of ex vivo models of either human or animal origin. The choice of an appropriate ex vivo model can be influenced by the storage, sample handling, preparation technique, and accurate experimental setup for the evaluation of the drug permeability. The selection of species is also an important factor to be considered. The comparison of some features of rat, mouse, pig, and human skins is summarized is Table 5 . The strength and weaknesses of different skin model diffusion objects are summarized in Table 6.

Table 4. Application possibilities of marketed RHE and LSE products.

Reconstructed Human Epidermis Models (RHE)

\begin{tabular}{|c|c|c|}
\hline Product & Manufacturer & Main Application Areas \\
\hline EpiDerm & MatTek Corporation, Ashland, MA, USA & $\begin{array}{l}\text { Skin irritation, skin corrosion, skin } \\
\text { hydration, dermal drug delivery, } \\
\text { phototoxicity, dermal genotoxicity, } \\
\text { epidermal differentiation }\end{array}$ \\
\hline EpiSkin & L'Oréal, Lyon, France & $\begin{array}{l}\text { Skin irritation, skin corrosion, UV } \\
\text { protection, bacterial adhesion, DNA } \\
\text { damage, dermal drug delivery }\end{array}$ \\
\hline SkinEthic & SkinEthic, Lyon, France & $\begin{array}{c}\text { Skin irritation, skin corrosion, UV } \\
\text { protection, bacterial adhesion, DNA } \\
\text { damage, dermal drug delivery, medical } \\
\text { devices }\end{array}$ \\
\hline SkinEthic RHPE & SkinEthic, Lyon, France & UV exposure, OMICS, depigmentation \\
\hline EpiCs & $\begin{array}{l}\text { CellSystems, Troisdorf, Germany } \\
\text { (HENKEL), Phenion }\end{array}$ & Skin irritation, skin corrosion \\
\hline EpiCs-M & $\begin{array}{l}\text { CellSystems, Troisdorf, Germany } \\
\text { (HENKEL), Phenion }\end{array}$ & $\begin{array}{l}\text { Skin irritation, skin corrosion, } \\
\text { pigmentation, environmental effects }\end{array}$ \\
\hline $\begin{array}{l}\text { open source reconstructed epidermis } \\
\text { model }\end{array}$ & Phenion, Düsseldorf, Germany & Skin irritation, skin corrosion \\
\hline
\end{tabular}

Straticell

Straticell, Les Isnes, Belgium
Skin aging, barrier function, damage related to light, acute inflammation, pigmentation, pollution, 
Table 4. Cont.

\begin{tabular}{|c|c|c|}
\hline \multicolumn{3}{|c|}{ Reconstructed Human Epidermis Models (RHE) } \\
\hline Product & Manufacturer & Main Application Areas \\
\hline EPI MODEL & Labcyte, Gamagori, Japan & Skin irritation, skin corrosion \\
\hline \multicolumn{3}{|c|}{ Full-Thickness (living) Human Skin Models (LSE) } \\
\hline EpiDermFT & MatTek Corporation, Ashland, MA, USA & $\begin{array}{l}\text { Anti-aging, wound healing, skin } \\
\text { hydration, UV protection }\end{array}$ \\
\hline Phenion Full-Thickness Skin & Phenion, Düsseldorf, Germany & $\begin{array}{l}\text { Skin physiology and biochemistry, } \\
\text { clinical dermatology, transdermal drug } \\
\text { delivery studies, skin penetration studies, } \\
\text { wound healing, toxicological assessment } \\
\text { of chemicals, analysis of environmental } \\
\text { effects on skin physiology, e.g., UV and } \\
\text { IR irradiation }\end{array}$ \\
\hline Phenion FT-AGED & Phenion, Düsseldorf, Germany & For testing skin aging \\
\hline GraftSkin & $\begin{array}{c}\text { AApligraf; Organogenesis, La Jolla, CA, } \\
\text { USA }\end{array}$ & $\begin{array}{l}\text { Wound and injuries, pressure ulcers, } \\
\text { varicose ulcers, etc. }\end{array}$ \\
\hline Vitrolife-Skin & Kyoto, Japan & Skin irritation, skin corrosion \\
\hline
\end{tabular}

Table 5. Comparison of the dermal barrier properties of four different species (modified from Liu et al., 2009 [49]).

\begin{tabular}{lcccc}
\hline & Mouse & Rat & Porcine & Human \\
\hline $\begin{array}{l}\text { Full skin thickness } \\
\text { (average) }\end{array}$ & $0.4-1 \mathrm{~mm}$ & $1-2 \mathrm{~mm}$ & $1.5-2 \mathrm{~mm}$ & $2-3 \mathrm{~mm}$ \\
\hline Epidermal thickness & $9.4-13.3 \mu \mathrm{m}$ & $21.7 \mu \mathrm{m}$ & $52-100 \mu \mathrm{m}$ & $50-100 \mu \mathrm{m}$ \\
\hline Stratum corneum & $2.9 \mu \mathrm{m}$ & $5 \mu \mathrm{m}$ & $12.28 \mu \mathrm{m}$ & $10-12.5 \mu \mathrm{m}$ \\
\hline Fixed skin & no & no & yes & yes \\
\hline Average hair density & $658 \mathrm{hairs} / \mathrm{cm}^{2}$ & $289 \mathrm{hairs} / \mathrm{cm}^{2}$ & 11 hairs $/ \mathrm{cm}^{2}$ & $11 \mathrm{hairs} / \mathrm{cm}^{2}$ \\
\hline
\end{tabular}

Table 6. Comparison of strengths and weaknesses of different in vitro and ex vivo skin models used in permeability studies (modified from Flaten et al., 2015 [2]).

\begin{tabular}{|c|c|c|}
\hline In Vitro/Ex Vivo Skin Models & Strengths & Weaknesses \\
\hline Silicone membranes & $\begin{array}{l}\text { Low cost } \\
\text { No storage problems } \\
\text { Reproducible }\end{array}$ & $\begin{array}{l}\text { Non-lipid based } \\
\text { Not good model of stratum corneum } \\
\text { Non-biological origin }\end{array}$ \\
\hline PAMPA & $\begin{array}{l}\text { Low cost } \\
\text { Storage for longer time } \\
\text { Reproducible } \\
\text { High throughput }\end{array}$ & $\begin{array}{l}\text { Synthetic lipids or non-lipid based } \\
\text { Not good model of stratum corneum } \\
\text { Non-biological origin }\end{array}$ \\
\hline PVPA & $\begin{array}{c}\text { Relatively low cost } \\
\text { Storage for longer time } \\
\text { Reproducible } \\
\text { Lipid composition can be modified } \\
\text { Parallelization }\end{array}$ & $\begin{array}{l}\text { Lipid structure is not characterized } \\
\text { Non-biological origin }\end{array}$ \\
\hline Skin cell cultures & $\begin{array}{c}\text { Cell lines or primary cultures are } \\
\text { available, } \\
\text { Monolayers and multiple layers can be } \\
\text { developed }\end{array}$ & $\begin{array}{l}\text { High permeability } \\
\text { Not sufficient barrier function } \\
\text { High costs, different } \mathrm{pH}\end{array}$ \\
\hline
\end{tabular}


Table 6. Cont.

\begin{tabular}{|c|c|c|}
\hline In Vitro/Ex Vivo Skin Models & Strengths & Weaknesses \\
\hline Reconstructed human skin equivalents & $\begin{array}{c}\text { Good reproducibility } \\
\text { Wide spectrum of applications }\end{array}$ & $\begin{array}{l}\text { High permeability } \\
\text { Not sufficient barrier function } \\
\text { High costs, different } \mathrm{pH}\end{array}$ \\
\hline \multicolumn{3}{|c|}{ Ex vivo skins } \\
\hline Snake & $\begin{array}{l}\text { Single animal provides repeated sheds } \\
\text { Multiple samples from one shed } \\
\text { Storage at room temperature }\end{array}$ & $\begin{array}{c}\text { No hair follicles } \\
\text { Not relevant skin metabolism } \\
\text { No living epidermis and dermis }\end{array}$ \\
\hline Mouse & $\begin{array}{c}\text { Easy handling } \\
\text { Convenient size } \\
\text { Hairless species also available }\end{array}$ & $\begin{array}{c}\text { Very thin skin, } \\
\text { High permeability } \\
\text { High density of hair follicles } \\
\text { Hair removal results in damage } \\
\text { Ethical issues, storage issues } \\
\text { Storage issues }\end{array}$ \\
\hline Rat & $\begin{array}{c}\text { Easy handling } \\
\text { Convenient size } \\
\text { Hairless species also available }\end{array}$ & $\begin{array}{l}\text { Thin skin, high permeability } \\
\text { High density of hair follicles } \\
\text { Hair removal results in damage } \\
\text { Ethical issues } \\
\text { Storage issues }\end{array}$ \\
\hline Pig & $\begin{array}{c}\text { Ears are easily obtained, similarity with } \\
\text { human skin }\end{array}$ & $\begin{array}{l}\text { Age and the anatomical region of the } \\
\text { animal influence the skin thickness, Hair } \\
\text { removal results in skin damage } \\
\text { Storage issues }\end{array}$ \\
\hline Rabbit & $\begin{array}{c}\text { Ears are easily obtained, similarity with } \\
\text { human skin }\end{array}$ & $\begin{array}{l}\text { High density of hair follicles } \\
\text { Hair removal results in damage } \\
\text { Ethical issues } \\
\text { Storage issues }\end{array}$ \\
\hline Guinea pig & $\begin{array}{l}\text { Similarity with human skin } \\
\text { Hairless species also available }\end{array}$ & $\begin{array}{l}\text { High density of hair follicles } \\
\text { Hair removal results in damage } \\
\text { Ethical issues } \\
\text { Storage issues }\end{array}$ \\
\hline Human & The most relevant model & $\begin{array}{l}\text { Inter- and intra-individual variability, } \\
\text { differences with age, sex, race, origin, } \\
\text { anatomical region }\end{array}$ \\
\hline
\end{tabular}

\section{Franz Diffusion Cell Studies at PPCU}

\subsection{Filter Paper and Artificial Membranes}

In our initial pilot experiments, filter paper (Whatman 50) and cellulose-acetate membrane (Sartorius) permeability was tested and compared to rat skin in Franz diffusion cells using caffeine cream as a hydrophilic model drug [50]. The degree of diffusion of the active molecule was proportional with the pore size of the diffusion object (filter paper: $2.7 \mu \mathrm{m}$, cellulose acetate membrane 0.45 and $0.8 \mu \mathrm{m}$ ) and the excised ex vivo rat skin permeability was comparable to $0.45 \mu \mathrm{m}$ membrane.

\subsection{Excised Skins of Different Species}

The next question to be discussed was the optimization of the degree of mechanical sensitization of the excised skin surface before the permeability experiments. This intervention helps to get higher drug concentrations in the receiver chamber of the diffusion cells to make the detection possible by different analytical techniques. For this purpose, different species (mouse, rat, pig, and human) were investigated and various numbers of tape stripping processes were applied $(0,5,10,20,30)$. The thinner skins (mouse, rat) needed less sensitization $(5,10)$ while the thicker skins expected more tape stripping 
$(20,30)$ for the proper permeability. Based on the results for the routine topical transport and absorption experiments, 10-fold sensitization was utilized in excised epilated rat skin.

Different topical drug formulations (e.g., erthromycine and Aknemycine creams or quinidine cream and gel) were also compared in Franz diffusion cells. The effect of skin sample freezing and thawing and the role of the age of the excised skins were also tested in some experiments. Both the freezing and the aging (2-3 months young and 16-22 months old rats were compared) influenced the drug absorption in a statistically significant manner. However, the lipophilic character of the test compounds was also a determining factor in this respect in transdermal delivery.

\section{Skin-on-a-Chip Technology at PPCU}

Skin-on-a-chip devices offer innovative and state-of-the-art platforms essential to overcome the limitations of other diffusion cell techniques [51]. In our laboratory, a novel microfluidic device concept has been designed for testing drug penetration through the skin (Figure 3). The generalized design is optimized for manufacturing with rapid prototyping techniques; CNC milling, polymer casting, laser cutting and 3D printing. The developed Microfluidic Diffusion Chamber (MDC) can be used for in vitro/ex vivo monitoring of the transdermal delivery of topical drugs.

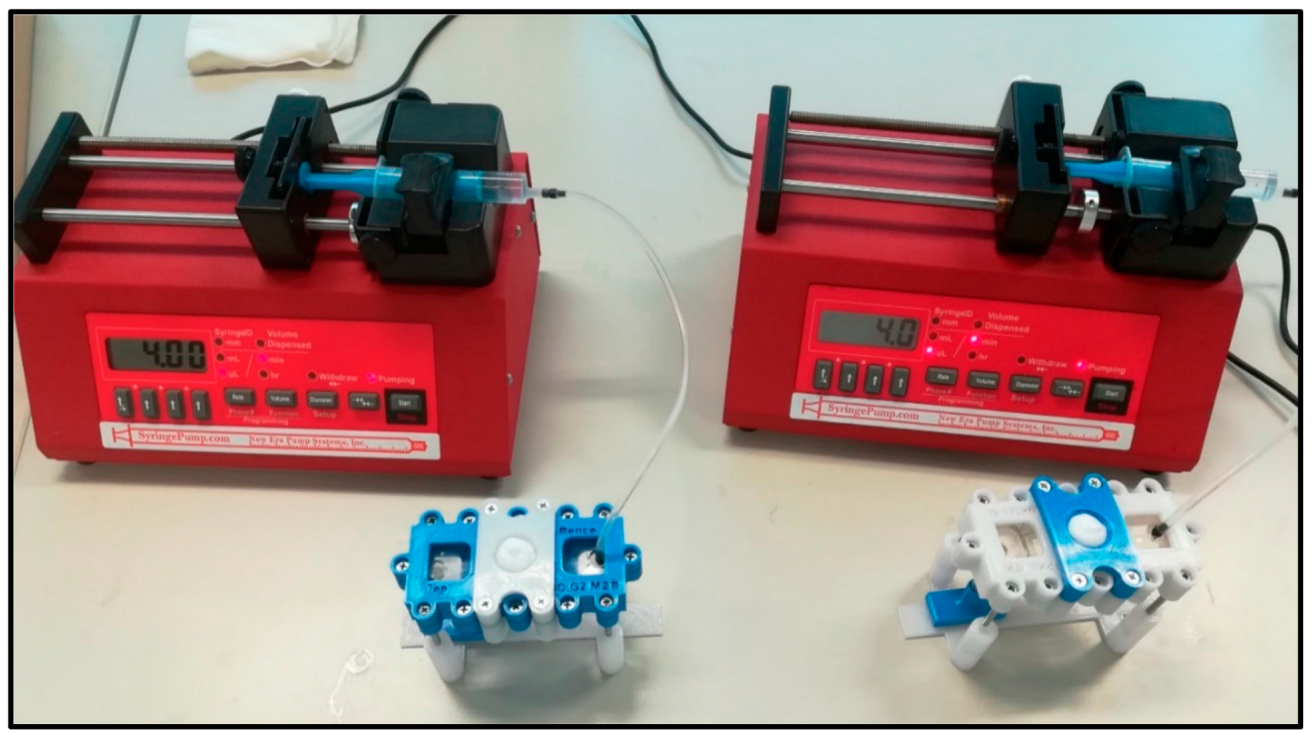

Figure 3. Two simultaneous "skin-on-a chip" experimental setups. The system consists of a programmable syringe pump and a flow-through dynamic microfluidic device [30]. The samples are collected below the diffusion system in the collection bench.

The generalized device design consists of three main parts: a polymer-based microfluidic channel assembly, a frame that surrounds the microfluidic channel system and a sample holder that holds and inserts the membrane (diffusion well or integrated skin sample) into the MDC. The device is fabricated using rapid prototyping technologies, which allow us to create multiple MDCs that have slight variations in their design according to the needs of the experiments. Such variations can be the presence or absence of a temperature control unit, the geometry of the microfluidic channel system, the construction of the membrane receiving area, or the configuration of the fluid inlet and outlet ports.

In all device generations, the polymer-based channel assembly is made from polydimethylsiloxane (PDMS) (SYLGARD ${ }^{\text {TM }} 184$ Silicone Elastomer Kit, Dow Consumer Solutions, Los Angeles, CA, USA). The microfluidic channel is created by mixing the PDMS liquid monomer and its treating agent at a $10: 1$ ratio and incubating it at $70^{\circ} \mathrm{C}$ for $2 \mathrm{~h}$ in a CNC milled casting mold made from acrylic or aluminum. The polymerized PDMS is cut to shape and punched through at the inlet and outlet ports. If the channel system is 
created from multiple PDMS parts, then the layers are held together by sandwiching them between laser-cut (Epilog Zing 16 Laser) poly(methyl methacrylate) (PMMA) plates. The microfluidic channel assembly is then inserted into the frame which is held together with bolts and nuts.

\subsection{The Device (First- and Second-Generations)}

The first-generation MDCs were designed and manufactured by Lukács et al. [29]. The chip was designed to be used with skin samples that are stretched at the bottom of the membrane holder. In this design, the membrane holder is merged with the donor compartment, creating a box-like shape that is conical in the inside. The examined substance (e.g., a cream) can be loaded into the cone-shaped funnel where at the bottom it is separated from the peripheral perfusion fluid (PPF) filled channels with the skin sample acting as the membrane. This generation of the device used a holder and frame made from polylactic acid (PLA) using 3D printing (CraftBot Plus 3D printer, CraftUnique Ltd., Budapest, Hungary).

A variation of this device included a combined heater-thermistor unit that could be used for the temperature control of the MDC. The heater unit was placed directly beneath the PDMS layers to ensure good thermal conductivity.

In some experiments, the PLA-based clamping device turned out to not be durable enough, the tensile strength and heat resistance of the PLA material was not sufficient; and the frame cracked under the stress. In these cases, the PLA material was substituted by polyethylene terephthalate glycol (PETG), which has better mechanical properties in this application.

The second generation was developed to correct the design flaws of the first generation as well as to implement a new sample insertion feature. The second-generation MDCs support two types of clamping devices, the one seen in the first generation and a new one that can be used for the insertion of transwell inserts into the chamber. The wells are placed directly onto the PDMS gel through a window in the acrylic sheet and then the well is pressed down using the well holder (Figure 4).
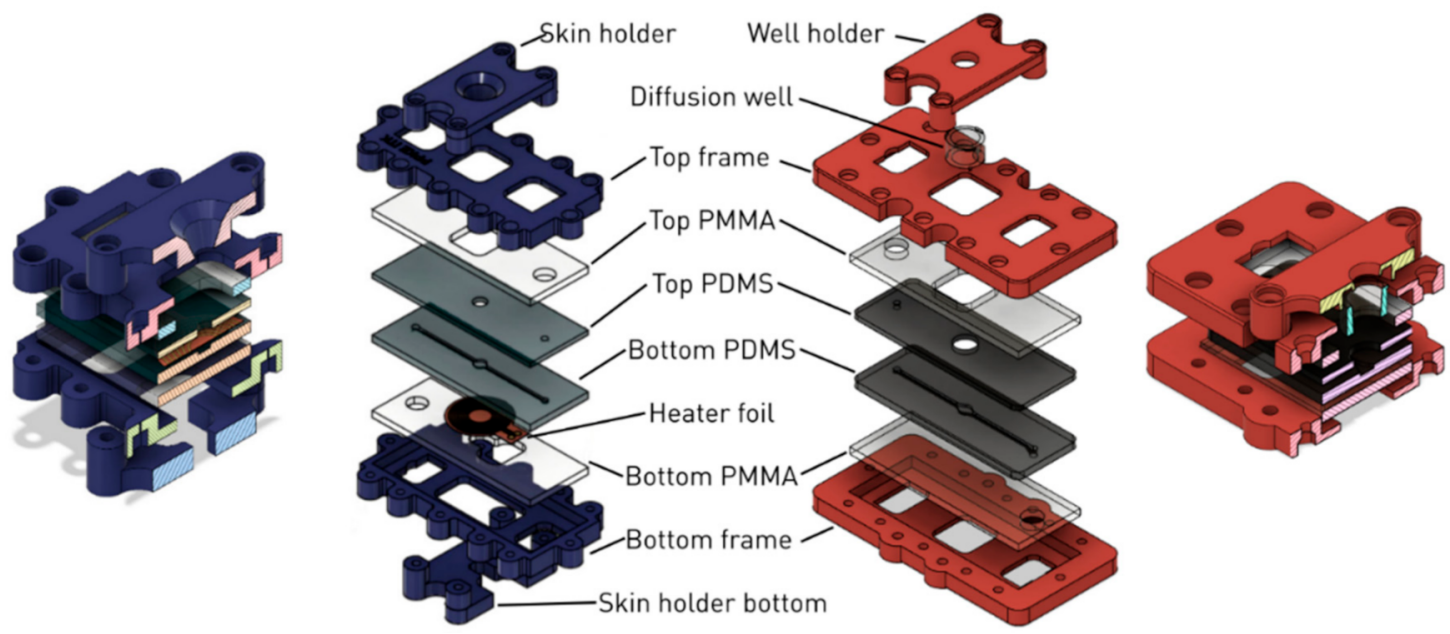

Figure 4. Exploded schematic view of the Microfluidic Diffusion Chamber (MDC) generations. Left (blue): Cross-sectional and layer-by-layer view of the first-generation temperature-controlled device with the skin sample holder. Right (red): Layer-by-layer and cross-sectional view of the second-generation device with a diffusion well holder.

The frames of the second-generation MDCs were made from PETG or Onyx, the latter is a micro carbon fiber filled nylon material with a very good tensile strength and heat resistance, manufactured by Markforged, Inc., Watertown, MA, U.S.A. Parts created from Onyx were printed on a Mark Two 3D printer (Markforged, Inc.). In some applications the frame and holder were further reinforced with embedded fiberglass or Kevlar (aramid) fibers. 


\section{Drug Penetration Studies}

During drug development, in addition to the development of the appropriate drug formulation, the penetration of a given drug is studied according to strict regulations (e.g., OECD, Guidance Notes on Dermal Absorption (No. 156) etc. [52-54]). Diffusion cells are most commonly used to study the penetration of drugs through the skin, many variants of which are known and available on the market (e.g., open, closed, vertical, horizontal cell, etc.) [55] (see also Table 1), but during the last years, skin-on-a-chip devices are also increasingly used for drug penetration studies [56]. The great advantages of these devices is that they mimic the skin microcircular perfusion by dynamic arrangement, they are simple to use and small in size (less tissue, cell, test substance, and vehicle demand).

At the laboratory of PPCU, drug penetration studies are performed with microfluidic chips, the structure of which is presented in details in Section 4.1. The topical drug absorption studies were preceded by device validation. In our experiments, caffeine was used as a hydrophilic model drug. Caffeine is widely used in topical formulations and is popular in the cosmetic industry for its beneficial effects on skin microcirculation and hair growth [50]. Moreover, caffeine is easily available, inexpensive, and measurable with a UV-VIS spectrophotometer at $273 \mathrm{~nm}$. During validation assays, cut-to-size, properly prepared filter paper, or cellulose acetate membranes of various pore size were placed in the middle compartment of the device [50,57], and then caffeine cream (cream composition described in Lukács, 2019 [29]) was placed in the microchip donor compartment with a Micromen device (positive replacement pipette). Peripheral perfusion fluid (PPF) was passed through the system at a rate of $4 \mu \mathrm{L} / \mathrm{min}$. Samples were collected and immediately placed onto dry ice and stored at $-75^{\circ} \mathrm{C}$ until the analytical investigation. The caffeine concentration of the samples was examined with a NanoDrop spectrophotometer. The intra- and inter-device differences were evaluated and compared. A good reproducibility was observed in the repeated experiments. The validation experiments were summarized in the BSc thesis of Lilla Friedreich [57].

In the first-generation skin-on-a-chip devices, the penetration of various drugs (e.g., caffeine, erythromycin, quinidine) was examined in mouse, rat and human excised skin samples. The differences between the species on freshly excised and frozen samples, as well as on native and mechanically sensitized samples (various numbers of adhesive tapestripping) were investigated [29]. In addition, young and old rat excised skin samples were also examined (both functionally and morphologically) in fresh and frozen samples, thus studying the changes that take place during the process of aging [30]. These studies were recently expanded to include the investigation of pathological skin samples in collaboration with the research group of Prof. Rolland Gyulai at University of Pécs. In these experiments, the drug permeability properties of imiquimod-induced psoriatic mouse skin samples were examined relative to samples from healthy animals and vehicle-treated controls (unpublished data). Our drug penetration studies with Franz diffusion cells as well as the skin-on-a-chip experiments were complemented by various microscopic techniques (scanning electronmicroscopy, two-photon microscopy) to analyze the morphology and structure of the uppermost layer and cross-sectional view of stratum corneum.

\section{Efflux Transporter Interaction Studies (Fresh and Frozen Tissue, Erythromycin, Quinidine)}

The transdermal delivery of efflux transporter substrates has also been examined using the Franz-diffusion cell and the MDC system, which are described in detail in our previous paper [30].

P-glycoprotein (P-gp, MDR1, ABCB1) is an extremely widespread transporter protein, it is expressed in almost all eukaryotic cell (including the different cell types of the human skin), and in parallel its substrate specificity is also exceedingly broad. We could demonstrate that P-gp is functional in the skin in vivo and ex vivo, moreover its transport mechanism contributes to the transdermal absorption.

In this project, the transdermal penetration profile of two P-glycoprotein substrates, erythromycin and quinidine, was investigated in the presence and absence of a P-gp 
inhibitor (PSC-833). The achievements showed the inhibitory effect of PSC-833 on the absorption of both tested compounds in the Franz diffusion cells and the MDC system. However, these effects were present only on freshly prepared skin samples, since the protein was damaged during the freezing and thawing of the skin samples, which increased the tissue permeability. Therefore, the use of frozen tissues is not recommended when studying the dermal barrier.

A further examined aspect is the effect of aging on the transporter function. It is known from the literature that the thickness and the water, collagen, and extracellular matrix contents of the aged skin are reduced, which might be the reason of the measured higher permeability rate of the aged skin for lipophilic drugs and lower permeability for special hydrophilic components.

It was also demonstrated that the magnitudes of the penetrated substrate concentrations are comparable in studies on the Franz-diffusion cells and on the MDCs, and only the shapes of the curves were different. While they are continuously ascending in the case of the Franz-diffusion cell system, the MDC results have an absorption-plateau-elimination three-phase profile. It corresponds to the differences in the dynamics of the fluid flow of the two systems. As mentioned before, the Franz cell is a static diffusion system, i.e., the penetrated compound is accumulated in the receptor fluid. Although in our $5 \mathrm{~h}$ long experiments only the absorption phase could be reached in case of erythromycin cream, when running the experiment for a longer time, after the absorptive period, a plateau phase is outlined (Figure 5A). However, by investigating the quinidine transport from the gel formulation, the three-phase concentration-time profiles have been achieved (Figure 5B). In the MDC system, a third elimination phase is also present because of the flow-through technique, where the drug might be washed out from the receptor compartment.
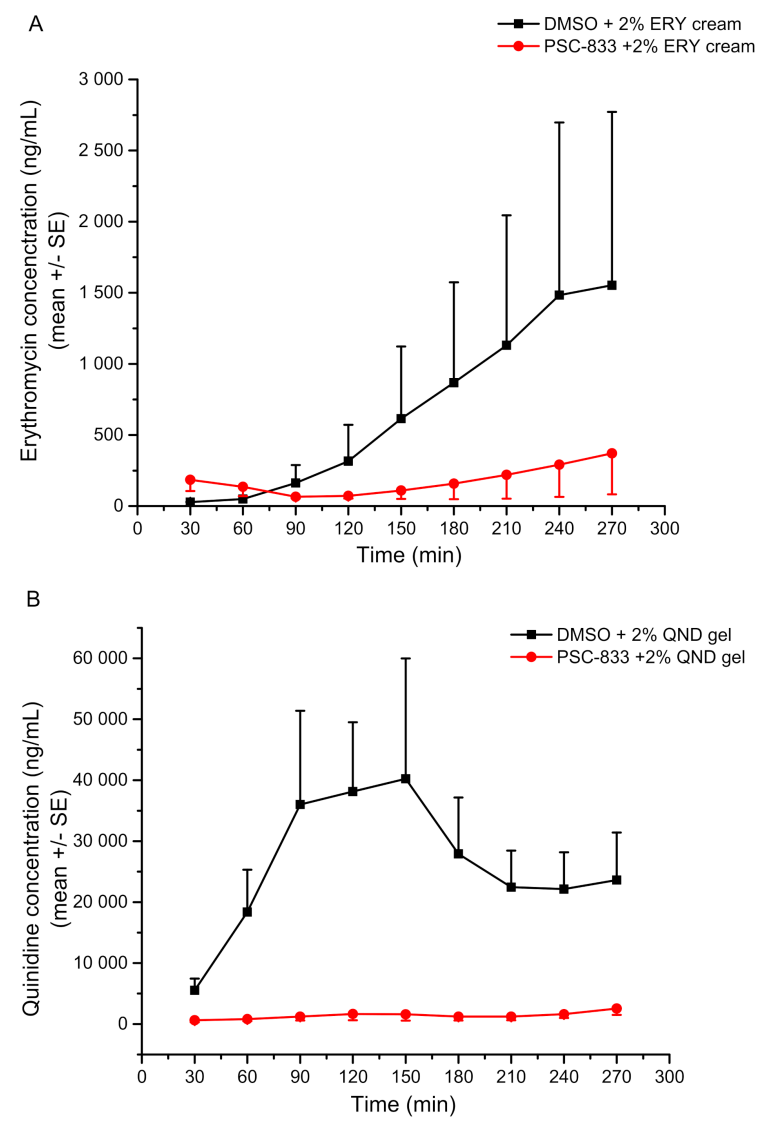

Figure 5. Skin penetration of erythromycin cream (ERY) and quinidine gel (QND) (Panel (A,B), respectively) across the freshly prepared excised young rat abdominal skin in the microfluidic chip. Concentration data are shown as means $+/-\mathrm{SE}, n=3-5$ [30]. The P-gp inhibitor (PSC-833) significantly reduced QND and ERY penetration through the skin. 
In conclusion, it was demonstrated that the MDC system can be utilized for the investigation of transporter interactions at the dermal barrier.

\section{Skin-Equivalent on a Chip Studies}

In recent years, there has been a gradual increase in social pressure to reduce the number of animal experiments. In modern societies, many different stringent laws and regulations have been introduced to meet this demand, including a ban on the use of animals in cosmetic experiments in the European Union since 2013. As a result, there has been a significant increase in the demand for alternatives that can fully elicit the role of animals in pharmaceutical and cosmetic research [58].

Skin is a large, heterogeneous, multilayered organ [59]. Due to its complexity, it is difficult to create a proper alternative that can model all the properties of the skin. In collaboration with a research group of Dr. András Czirok at Eötvös Loránd University (Budapest), a measurement system has been created in which the transport of caffeine was successfully examined through a skin equivalent placed in a validated microfluidic chamber. The skin substituent was based on a polycaprolactone (PCL) membrane made by electrospinning $[60,61]$. Polycaprolactone was used as a scaffold for artificial skin due to its biocompatibility and slow biodegradation [60]. Electrospinning is a versatile technique with a wide range of applications, one of which is biomedical use [61]. The technique makes it possible to produce fibers not only in the micrometer but also in the nanometer range by adjusting the parameters, thereby creating structures that are able to mimic the natural cellular matrix. Our PCL mesh was placed on a 3D printed sample holder consisting of two elements and then the main cylindric element of the sample holder was loaded with collagen-1 gel. HaCaT immortalized human keratinocytes were implanted on the mesh and placed in the sample holder, which attached to the membrane to form a confluent monolayer. During the measurements, the transport of caffeine across the artificial skin equivalent was compared with the human excised skin samples, the results of which showed similar transport kinetics [58] (Figure 6).

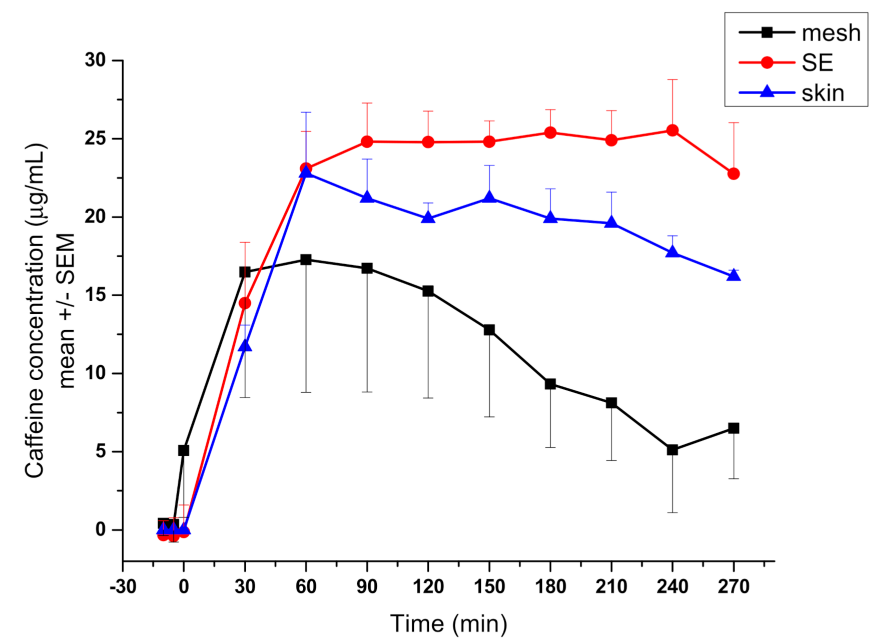

Figure 6. Transdermal transport measurements using skin equivalent (SE) and human skin. Caffeine concentration in the collected fractions was measured by spectrophotometry and is shown as a function of time [58]. The difference between concentration readings from the marked mesh-only and SE samples is significant ( $p=1.2 \times 10^{-7}, n=12$ in each group).

\section{Discussion}

As it was demonstrated in the previous paragraphs, the physiological relevance of dermal diffusion models has been improved by various technologies to obtain more accurate and reproducible results in drug and cosmetic research. The current article intended to show some recent advancements in the field of skin-on-a-chip technology achieved at Pázmány Péter Catholic University, a new player of Hungarian medical- 
biotechnology research. Some details of design, engineering, and manufacturing of the new microfluidic platforms were described and also a few examples of the validation experiments and the major running projects for the utilization of the microchip device were presented. At this phase of the developments, mainly excised human and animal skins and $\mathrm{HaCaT}$ cell-based human skin equivalents are used as diffusion platforms. For future directions, more relevant biological platforms are planned to be created and mounted on the chips (e.g., human reconstructed skin and organ substituents with parallelization) [62]. Additionally, organ-organ interactions should be considered at the design and fabrication of novel miniaturized investigational platforms in the pharmaceutical and cosmetical testing laboratories [63].

As the properties of in vitro skin diffusion testing platforms are improving, they have many advantages contrary to the use of in vivo systems. However, they still have some cons as well (Table 7). Therefore, at the selection of the proper permeability model, the purpose of the study and all these aspects need to be considered.

Table 7. Advantages and limitations of the use of in vitro skin assays contrary to the in vivo models.

\begin{tabular}{ll}
\hline \multicolumn{1}{c}{ Pros } & \multicolumn{1}{c}{ In Vitro Skin Permeation Studies } \\
\hline $\begin{array}{l}\text { Reduce the number of experimental animals } \\
\text { No ethical issues }\end{array}$ & $\begin{array}{l}\text { Physiologically limited relevance } \\
\text { Lower complexity of the test system } \\
\text { Good reproducibility }\end{array}$ \\
$\begin{array}{l}\text { Focuses only on one target } \\
\text { Relatively fast }\end{array}$ & Not all dermal cell types are included \\
Lower costs than the in vivo & No proper circulation \\
Lower standard errors & No immunological reactions \\
Can be more specific & \\
Mechanistic approach & \\
Human cells/tissues can be used, high relevance & \\
\hline
\end{tabular}

To further generate more reliable in vitro skin-on-a-chip models, there is a growing interest in integrating different additional skin components, such as microvasculature, immune cells, and hair follicles into the complexity of cell cultures on the diffusion surface of microfluidic devices. On the other hand, some additional factors such as the skin of different populations (pediatric, adult, elderly, different ethnicity, diseased) or different anatomical regions (face, neck, scalp, forehead, upper arm, lower leg, upper leg, inner forearm, outer forearm, back, abdomen, etc.) $[64,65]$ should also be considered when ex vivo models are evaluated.

These days in silico models greatly help the planning of in vitro/ex vivo testing and contribute to the reduction of in vivo models. On the other hand, the in silico methods are often supported by strong in vitro data and can provide timely results, bringing down costs and the need for extensive biological studies. The in vivo testing can be limited and a large proportion of the required criteria can be planned and met in silico [66,67].

The microfluidic devices and the novel testing technology worked out at Pázmány Péter Catholic University will be further developed, but they are available in the current form for other laboratories and for interested research groups as well.

Author Contributions: Conceptualization, writing—original draft: F.E., Z.V.-M., D.K., M.B.N. and K.F.; funding acquisition F.E. All authors have read and agreed to the published version of the manuscript.

Funding: Project no. ED_17-1-2017-0009 has been implemented with the support provided by the National Research, Development, and Innovation Fund of Hungary, financed under the National Bionics Program funding scheme. 
Institutional Review Board Statement: The excised human tissue was purchased from the plastic surgery clinics (Révész Plasztika, Budapest, Hungary) and used in the experiments based on the ethical permission 6501-6/2019/EKU of TUKEB, Budapest, Hungary.

Data Availability Statement: The data of our experiments can be found in the laboratory archive.

Acknowledgments: The authors are grateful to Kristóf Iván for the funding acquisition and to Rózsa Molnár, Lilla Friedreich, and Orsolya Berezvai, who were involved in the validation studies of Franz diffusion cells and skin-on-a-chip device. Many thanks to Bence Lukács for manufacturing the first prototype of the microfluidic diffusion cell.

Conflicts of Interest: The authors declare no conflict of interest.

\section{References}

1. Maharao, N.; Antontsev, V.; Hou, H.; Walsh, J.; Varshney, J. Scalable in silico Simulation of Transdermal Drug Permeability: Application of BIOiSIM Platform. Drug Des. Dev. Ther. 2020, 14, 2307-2317. [CrossRef]

2. Flaten, G.E.; Palac, Z.; Engesland, A.; Filipović-Grčić, J.; Vanić, Ž.; Škalko-Basnet, N. In vitro skin models as a tool in optimization of drug formulation. Eur. J. Pharm. Sci. 2015, 75, 10-24. [CrossRef] [PubMed]

3. Pasparakis, M.; Haase, I.; Nestle, F.O. Mechanisms regulating skin immunity and inflammation. Nat. Rev. Immunol. 2014, 14, 289-301. [CrossRef]

4. Pupovac, A.; Senturk, B.; Griffoni, C.; Maniura, K.; Rottmar, M.; McArthur, S.L. Toward Immunocompetent 3D Skin Models. Adv. Healthc. Mater. 2018, 7, e1701405. [CrossRef]

5. Groeber, F.; Holeiter, M.; Hampel, M.; Hinderer, S.; Schenke-Layland, K. Skin tissue engineering — In vivo and in vitro applications. Adv. Drug Deliv. Rev. 2011, 63, 352-366. [CrossRef] [PubMed]

6. Griffoni, C.; Neidhart, B.; Yang, K.; Groeber-Becker, F.; Maniura-Weber, K.; Dandekar, T.; Walles, H.; Rottmar, M. In vitro skin culture media influence the viability and inflammatory response of primary macrophages. Sci. Rep. 2021, 11, 1-11. [CrossRef]

7. Seo, M.-D.; Kang, T.-J.; Lee, C.-H.; Lee, A.-Y.; Noh, M. HaCaT Keratinocytes and Primary Epidermal Keratinocytes Have Different Transcriptional Profiles of Cornified Envelope-Associated Genes to T Helper Cell Cytokines. Biomol. Ther. 2012, 20, 171-176. [CrossRef] [PubMed]

8. Franz, T.J. Percutaneous Absorption. On the Relevance of in Vitro Data. J. Investig. Dermatol. 1975, 64, 190-195. [CrossRef] [PubMed]

9. Borbás, E.; Balogh, A.; Bocz, K.; Müller, J.; Kiserdei, É.; Vigh, T.; Sinkó, B.; Marosi, A.; Halász, A.; Dohányos, Z.; et al. In vitro dissolution-permeation evaluation of an electrospun cyclodextrin-based formulation of aripiprazole using $\mu$ Flux ${ }^{\mathrm{TM}}$. Int. J. Pharm. 2015, 491, 180-189. [CrossRef] [PubMed]

10. Bartos, C.; Szabó-Révész, P.; Horváth, T.; Varga, P.; Ambrus, R. Comparison of Modern In Vitro Permeability Methods with the Aim of Investigation Nasal Dosage Forms. Pharmaceutics 2021, 13, 846. [CrossRef]

11. Introduction to NaviCyte I Warner Instruments. Available online: https://www.warneronline.com/introduction-to-navicyte (accessed on 31 August 2021).

12. García, J.; Méndez, D.; Álvarez, M.; Sanmartin, B.; Vázquez, R.; Regueiro, L.; Atanassova, M. Design of novel functional food products enriched with bioactive extracts from holothurians for meeting the nutritional needs of the elderly. LWT 2019, 109, 55-62. [CrossRef]

13. Ramsay, E.; del Amo, E.M.; Toropainen, E.; Tengvall-Unadike, U.; Ranta, V.-P.; Urtti, A.; Ruponen, M. Corneal and conjunctival drug permeability: Systematic comparison and pharmacokinetic impact in the eye. Eur. J. Pharm. Sci. 2018, 119, 83-89. [CrossRef] [PubMed]

14. Bejgum, B.C.; Donovan, M.D. Uptake and Transport of Ultrafine Nanoparticles (Quantum Dots) in the Nasal Mucosa. Mol. Pharm. 2021, 18, 429-440. [CrossRef] [PubMed]

15. Teixeira, L.D.S.; Chagas, T.V.; Alonso, A.; Gonzalez-Alvarez, I.; Bermejo, M.; Polli, J.; Rezende, K.R. Biomimetic Artificial Membrane Permeability Assay over Franz Cell Apparatus Using BCS Model Drugs. Pharmaceutics 2020, 12, 988. [CrossRef] [PubMed]

16. Seo, J.-E.; Kim, S.; Kim, B.-H. In vitro skin absorption tests of three types of parabens using a Franz diffusion cell. J. Expo. Sci. Environ. Epidemiol. 2016, 27, 320-325. [CrossRef]

17. Fernández-Campos, F.; Clares, B.; Rodríguez-Lagunas, M.J.; Jauregui, O.; Casals, I.; Calpena, A.C.; Campos, F.-; Lagunas, R.-. Ex-Vivo and In-Vivo Assessment of Cyclamen europaeum Extract After Nasal Administration. Pharmaceutics 2019, 11, 426. [CrossRef]

18. Toffoletto, N.; Chauhan, A.; Alvarez-Lorenzo, C.; Saramago, B.; Serro, A. Asymmetry in Drug Permeability through the Cornea. Pharmaceutics 2021, 13, 694. [CrossRef] [PubMed]

19. Iii, M.G.L.; Shankar, R.K.; Yang, H. Chitosan nanofibers for transbuccal insulin delivery. J. Biomed. Mater. Res. Part A 2017, 105, 1252-1259. [CrossRef]

20. Cordoba-Diaz, M.; Nova, M.; Elorza, B.; Chantres, J.; Córdoba-Borrego, M. Validation protocol of an automated in-line flowthrough diffusion equipment for in vitro permeation studies. J. Control. Release 2000, 69, 357-367. [CrossRef] 
21. Díaz, D.C.; Iglesias, M.E.L.; Vallejo, R.B.D.B.; Diaz, M.C. Transungual Delivery of Ciclopirox Is Increased 3-4-Fold by Mechanical Fenestration of Human Nail Plate in an In Vitro Model. Pharmaceutics 2019, 11, 29. [CrossRef]

22. Xiang, J.; Fang, X.; Li, X. Transbuccal delivery of $2^{\prime}, 3^{\prime}$-dideoxycytidine: In vitro permeation study and histological investigation. Int. J. Pharm. 2002, 231, 57-66. [CrossRef]

23. Upadhyay, Y.; Singh, A.K.; Mishra, S.; Gurule, S.J.; Khuroo, A.H.; Tiwari, N.; Bedi, S. Comparison of In Vitro Release Rates of Diclofenac Topical Formulations Using an In-Line Cell Automated Diffusion System. Dissolution Technol. 2019, $26,10-16$. [CrossRef]

24. Avdeef, A.; Tsinman, O. PAMPA-A drug absorption in vitro model: 13 . Chemical selectivity due to membrane hydrogen bonding: In combo comparisons of HDM-, DOPC-, and DS-PAMPA models. Eur. J. Pharm. Sci. 2006, 28, 43-50. [CrossRef] [PubMed]

25. Punyamurthula, N.S.; Adelli, G.R.; Gul, W.; Repka, M.A.; ElSohly, M.A.; Majumdar, S. Ocular Disposition of $\Delta 8-$ Tetrahydrocannabinol from Various Topical Ophthalmic Formulations. AAPS PharmSciTech 2016, 18, 1936-1945. [CrossRef] [PubMed]

26. Bakand, S.; Winder, C.; Hayes, A. Cell Viability and Cytokine Production of Human Alveolar Epithelial Cells Following Exposure to Sulphur Dioxide. Int. J. Occup. Hyg. 2011, 3, 63-69.

27. Zhang, B.; Korolj, A.; Lai, B.F.L.; Radisic, M. Advances in organ-on-a-chip engineering. Nat. Rev. Mater. 2018, 3, 257-278. [CrossRef]

28. Wu, Q.; Liu, J.; Wang, X.; Feng, L.; Wu, J.; Zhu, X.; Wen, W.; Gong, X. Organ-on-a-chip: Recent breakthroughs and future prospects. Biomed. Eng. Online 2020, 19, 1-19. [CrossRef]

29. Lukács, B.; Bajza, Á.; Kocsis, D.; Csorba, A.; Antal, I.; Iván, K.; Laki, A.J.; Erdo, F. Skin-on-a-Chip Device for Ex Vivo Monitoring of Transdermal Delivery of Drugs-Design, Fabrication, and Testing. Pharmaceutics 2019, 11, 445. [CrossRef]

30. Bajza, Á.; Kocsis, D.; Berezvai, O.; Laki, A.J.; Lukács, B.; Imre, T.; Iván, K.; Szabó, P.; Erdő, F. Verification of P-Glycoprotein Function at the Dermal Barrier in Diffusion Cells and Dynamic "Skin-On-A-Chip" Microfluidic Device. Pharmaceutics 2020, 12, 804. [CrossRef]

31. Sharadha, M.; Gowda, D.V.; Gupta, V.; Akhila, A.R. An overview on topical drug delivery system-Updated review. Int. J. Res. Pharm. Sci. 2020, 11, 368-385. [CrossRef]

32. Eisinger, M.; Lee, J.S.; Hefton, J.M.; Darzynkiewicz, Z.; Chiao, J.W.; de Harven, E. Human epidermal cell cultures: Growth and differentiation in the absence of differentiation in the absence of dermal components or medium supplements. Proc. Natl. Acad. Sci. USA 1979, 76, 5340-5344. [CrossRef]

33. Green, H.; Kehinde, O.; Thomas, J. Growth of cultured human epidermal cells into multiple epithelia suitable for grafting. Proc. Natl. Acad. Sci. USA 1979, 76, 5665-5668. [CrossRef]

34. Rheinwatd, J.G.; Green, H. Seria cultivation of strains of human epidemal keratinocytes: The formation keratinizin colonies from single cell is. Cell 1975, 6, 331-343. [CrossRef]

35. O'Connor, N.; Mulliken, J.; Banks-Schlegel, S.; Kehinde, O.; Green, H. Grafting of burns with cultured epithelium prepared from autologous epidermal cells. Lancet 1981, 317, 75-78. [CrossRef]

36. Green, H. Terminal differentiation of cultured human epidermal cells. Cell 1977, 11, 405-416. [CrossRef]

37. Wufuer, M.; Lee, G.H.; Hur, W.; Jeon, B.; Kim, B.J.; Choi, T.H.; Lee, S.H. Skin-on-a-chip model simulating inflammation, edema and drug-based treatment. Sci. Rep. 2016, 6, 37471. [CrossRef]

38. Mazzoleni, G.; Di Lorenzo, D.; Steimberg, N. Modelling tissues in 3D: The next future of pharmaco-toxicology and food research? Genes Nutr. 2009, 4, 13-22. [CrossRef] [PubMed]

39. Van Gele, M.; Geusens, B.; Brochez, L.; Speeckaert, R.; Lambert, J. Three-dimensional skin models as tools for transdermal drug delivery: Challenges and limitations. Expert Opin. Drug Deliv. 2011, 8, 705-720. [CrossRef] [PubMed]

40. Godin, B.; Touitou, E. Transdermal skin delivery: Predictions for humans from in vivo, ex vivo and animal models. Adv. Drug Deliv. Rev. 2007, 59, 1152-1161. [CrossRef]

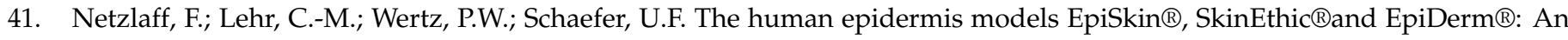
evaluation of morphology and their suitability for testing phototoxicity, irritancy, corrosivity, and substance transport. Eur. J. Pharm. Biopharm. 2005, 60, 167-178. [CrossRef] [PubMed]

42. MatTek Life Sciences. Available online: https:/ /www.mattek.com/products/ (accessed on 18 October 2021).

43. Episkin—World Leader in Tissue Engineering for in Vitro Human Skin and Epithelial Models. Available online: https://www. episkin.com/ (accessed on 18 October 2021).

44. Reconstructed Tissues. Available online: https:/ /www.phenion.com/products/reconstructed-tissues (accessed on 18 October 2021).

45. StratiCELL I Smart Science Dedicated to Skin Care. Available online: https://straticell.com/ (accessed on 18 October 2021).

46. Cultured Human Tissue for Research Use -LabCyte EPI-MODEL- I Japan Tissue Engineering Co., Ltd. (J-TEC). Available online: https://www.jpte.co.jp/en/business/LabCyte/epi-model/index.html (accessed on 18 October 2021).

47. Apligraf®Living Cellular Skin Substitute. Available online: https://apligraf.com/ (accessed on 18 October 2021).

48. Vitrolife-G-IVFTM PLUS. Available online: https://www.vitrolife.com/products/ivf-media--oil/g-ivf/ (accessed on 18 October 2021). 
49. Liu, J.; Kim, D.; Brown, L.; Madsen, T.; Bouchard, G.F. Comparison of Human, Porcine \& Rodent Wound Healing with New Miniature Swine Study Data 2009. Available online: https:/ /info.sinclairresearch.com/comparison-of-human-porcine-rodentwound-healing-with-new-miniature-swine-study-data (accessed on 21 August 2021).

50. Farner, F.; Bors, L.; Bajza, Á.; Karvaly, G.; Antal, I.; Erdő, F. Validation of an In vitro-in vivo Assay System for Evaluation of Transdermal Delivery of Caffeine. Drug Deliv. Lett. 2019, 9, 15-20. [CrossRef]

51. Öztürk, A.B.; Miccoli, B.; Avci-Adali, M.; Mogtader, F.; Sharifi, F.; Çeçen, B.; Yasayan, G.; Braeken, D.; Alarcin, E. Current Strategies and Future Perspectives of Skin-on-a-Chip Platforms: Innovations, Technical Challenges and Commercial Outlook. Curr. Pharm. Des. 2019, 24, 5437-5457. [CrossRef]

52. OECD Test. No. 427: Skin Absorption: In Vivo Method. In Guideline No. 497: Defined Approaches on Skin Sensitisation; Organisation for Economic Co-Operation and Development (OECD): Paris, France, 2004.

53. OECD Test. No. 428: Skin Absorption: In Vitro Method. In OECD Guidelines for the Testing of Chemicals, Section 4; OECD: Paris, France, 2004.

54. Buist, H.; Craig, P.; Dewhurst, I.; Bennekou, S.H.; Kneuer, C.; Machera, K.; Pieper, C.; Marques, D.C.; Guillot, G.; Ruffo, F.; et al Guidance on dermal absorption. EFSA J. 2017, 15, e04873. [CrossRef] [PubMed]

55. Zsikó, S.; Csányi, E.; Kovács, A.; Budai-Szúcs, M.; Gácsi, A.; Berkó, S. Methods to Evaluate Skin Penetration In Vitro. Sci. Pharm. 2019, 87, 19. [CrossRef]

56. Alberti, M.; Dancik, Y.; Sriram, G.; Wu, B.; Teo, Y.L.; Feng, Z.; Bigliardi-Qi, M.; Wu, R.G.; Wang, Z.P.; Bigliardi, P.L. Multi-chamber microfluidic platform for high-precision skin permeation testing. Lab Chip 2017, 17, 1625-1634. [CrossRef]

57. Friedreich, L. Evaluation of the Accuracy of Series Product Microfluidic Cells by a Caffeine Formulation. Bachelor's Thesis, Pázmány Péter Catholic University, Budapest, Hungary, 2020. (In Hungarian)

58. Tárnoki-Zách, J.; Mehes, E.; Varga-Medveczky, Z.; Isai, D.; Barany, N.; Bugyik, E.; Revesz, Z.; Paku, S.; Erdo, F.; Czirok, A Development and Evaluation of a Human Skin Equivalent in a Semiautomatic Microfluidic Diffusion Chamber. Pharmaceutics 2021, 13, 910. [CrossRef] [PubMed]

59. Benson, H.A.; Grice, J.E.; Mohammed, Y.; Namjoshi, S.; Roberts, M.S. Topical and Transdermal Drug Delivery: From Simple Potions to Smart Technologies. Curr. Drug Deliv. 2019, 16, 444-460. [CrossRef]

60. Van der Schueren, L.; De Schoenmaker, B.; Kalaoglu, Ö.I.; De Clerck, K. An alternative solvent system for the steady state electrospinning of polycaprolactone. Eur. Polym. J. 2011, 47, 1256-1263. [CrossRef]

61. Agarwal, S.; Wendorff, J.H.; Greiner, A. Use of electrospinning technique for biomedical applications. Polymer 2008, 49 , 5603-5621. [CrossRef]

62. Risueño, I.; Valencia, L.; Jorcano, J.L.; Velasco, D. Skin-on-a-chip models: General overview and future perspectives. APL Bioeng. 2021, 5, 030901. [CrossRef]

63. Zhang, Q.; Sito, L.; Mao, M.; He, J.; Zhang, Y.S.; Zhao, X. Current advances in skin-on-a-chip models for drug testing. Microphysiological Syst. 2018, 1, 1. [CrossRef]

64. Roberts, M.S.; Cheruvu, H.S.; Mangion, S.E.; Alinaghi, A.; Benson, H.A.; Mohammed, Y.; Holmes, A.; van der Hoek, J.; Pastore, M.; Grice, J.E. Topical drug delivery: History, percutaneous absorption, and product development. Adv. Drug Deliv. Rev. 2021, 177, 113929. [CrossRef] [PubMed]

65. Law, R.M.; Ngo, M.A.; Maibach, H.I. Twenty Clinically Pertinent Factors/Observations for Percutaneous Absorption in Humans. Am. J. Clin. Dermatol. 2020, 21, 85-95. [CrossRef] [PubMed]

66. Puttrevu, S.; Arora, S.; Polak, S.; Patel, N. Physiologically Based Pharmacokinetic Modeling of Transdermal Selegiline and Its Metabolites for the Evaluation of Disposition Differences between Healthy and Special Populations. Pharmaceutics 2020, $12,942$. [CrossRef] [PubMed]

67. Tsakalozou, E.; Babiskin, A.; Zhao, L. Physiologically-based pharmacokinetic modeling to support bioequivalence and approval of generic products: A case for diclofenac sodium topical gel, 1\%. CPT Pharmacomet. Syst. Pharmacol. 2021, 10, 399-411. [CrossRef] 